\title{
A review of influenza vaccine immunogenicity and efficacy in HIV-infected adults
}

\author{
Curtis Cooper MD FRCPC ${ }^{1}$, Brian Hutton $\mathrm{PhD}^{1}$, Dean Fergusson $\mathrm{PhD}^{1}$, Edward Mills $\mathrm{PhD}^{2}$, \\ Marina B Klein MD FRCPC ${ }^{3}$, Guy Boivin MD FRCPC ${ }^{4}$, Scott Halperin MD FRCPC ${ }^{5}$
}

\begin{abstract}
C Cooper, B Hutton, D Fergusson, et al. A review of influenza vaccine immunogenicity and efficacy in HIV-infected adults. Can J Infect Dis Med Microbiol 2008;19(6):419-423.
\end{abstract}

BACKGROUND: HIV-seropositive adults are at an increased risk for influenza infection. They also develop more severe influenza disease and are hyporesponsive to current influenza vaccinations.

METHODS: The authors examined findings from a systematic review of influenza vaccination in HIV-seropositive adults, and evaluated other relevant studies. A narrative overview of findings formulated to summarize the implications of currently available literature is presented. The primary goal of the present review is to assess the limitations of current evidence and to provide a framework for additional research.

RESULTS: There is a paucity of knowledge regarding the relative value of prophylactic influenza vaccination in HIV-positive adults compared with immunocompetent populations. There are shortcomings related to study methodology and temporal changes in the characteristics of patient baseline immune status, which limit the utility of this information to shape public health policy.

CONCLUSIONS: There is a pressing need to pursue methodologically rigorous studies that will increase knowledge related to improving the effectiveness of preventive influenza measures in this patient population.

Key Words: HIV; Immunocompromised; Influenza; Vaccine

\section{Revue de l'immunogénicité et de l'efficacité d'un vaccin antigrippal chez des adultes porteurs du VIH}

\begin{abstract}
HISTORIQUE : Les adultes VIH-positifs sont plus à risque à l'égard de la grippe; ses manifestations sont plus graves et les patients répondent moins bien aux vaccins antigrippaux actuels.

MÉTHODES : Les auteurs ont analysé les résultats d'une revue systématique des articles parus sur la vaccination antigrippale chez des adultes VIH-séropositifs et ont également évalué d'autres études pertinentes. Ils présentent un compte rendu narratif des conclusions formulées par ces études récentes pour en résumer la portée. Le principal objectif de la présente revue est de mesurer les limites des preuves actuelles et de fournir un cadre pour la poursuite de la recherche dans ce domaine. RÉSULTATS : Les auteurs déplorent le manque de données factuelles sur l'utilité relative des vaccins antigrippaux prophylactiques chez les adultes VIH-positifs par opposition à aux populations immunocompétentes. Ils constatent certaines lacunes sur le plan de la méthodologie des études et une variabilité dans le temps quant aux caractéristiques du statut immunitaire de base des patients, ce qui rend ces données pour ainsi dire inutilisables pour l'élaboration de politiques de santé publique.

CONCLUSIONS : Il est urgent de procéder à des études méthodologiquement rigoureuses qui nous permettront d'approfondir nos connaissances, si nous voulons améliorer l'efficacité des mesures de prévention de la grippe chez cette population de patients.
\end{abstract}

$\mathrm{T}_{\mathrm{a}}^{\mathrm{h}} \mathrm{n}$ he burden of HIV infection in Canada and other industrialized countries is great (1). As a consequence of a compromised immune status, this population is at risk for severe influenza illness. Influenza viral replication and shedding is prolonged, and the duration of influenza symptomatology is longer in those with HIV $(2,3)$. Furthermore, influenza-related mortality rates in HIV-infected individuals have increased (4). Influenza vaccination is recommended for HIV-infected individuals $(5,6)$. The Centers for Disease Control and Prevention (USA) guidelines state that "influenza can result in serious illness and because vaccination with inactivated influenza vaccine might result in the production of protective antibody titers, vaccination might benefit HIV-infected persons. Therefore, influenza vaccination is recommended" (6).

Despite evidence of influenza vaccine efficacy in HIV, this may be diminished compared with immunocompetent populations (7). Because influenza vaccination is the cornerstone of public health interventions intended to protect the population against influenza, vaccine hyporesponsiveness in HIV represents a significant concern. In view of the risk of influenza exposure in general, as well as concerns related to poor vaccine efficacy and more severe influenza disease in those living with HIV, strategies to improve vaccine efficacy are required. The present article reviews the current burden of influenza in HIV patients and the shortcomings of existing research in this field. The implications of suboptimal influenza vaccine effectiveness and the need for new strategies for influenza prevention in this population are discussed.

\section{METHODS}

To identify relevant literature for the present systematic review, a search strategy was established in consultation with a medical librarian. The following databases were searched independently and in duplicate (from inception to June 2007) MEDLINE, EMBASE (Excerpta Medica), Cochrane Central Register of Controlled Trials, Allied and Complementary Medicine Database, Cumulative Index to Nursing and Allied Health Literature, TOXNET, Development and Reproductive

${ }^{1}$ University of Ottawa, Division of Infectious Diseases - The Ottawa Hospital, Ottawa Health Research Institute - Methods Centre, Ottawa,

Ontario; ${ }^{2}$ The University of British Columbia, Vancouver, British Columbia; ${ }^{3} \mathrm{McGill}$ University, Montreal; ${ }^{4}$ Laval University, Laval,

Quebec; ${ }^{5}$ Dalhousie University, Halifax, Nova Scotia

Correspondence: Dr Curtis Cooper, University of Ottawa, Division of Infectious Diseases - The Ottawa Hospital, Ottawa Health Research

Institute - Methods Centre, G12-501 Smyth Road, Ottawa, Ontario K1H 8L6. Telephone 613-737-8924, fax 613-737-8164,

e-mail ccooper@ottawahospital.on.ca

Received for publication March 11, 2008. Accepted July 17, 2008 
Toxicology, Hazardous Substances Databank, PsychINFO and Web of Science, and databases that included the full text of journals (OVID, ScienceDirect, and Ingenta), including articles in full text from approximately 1700 journals since 1993. The bibliographies of published systematic reviews and protocols were also evaluated.

\section{AN IMPORTANT PROBLEM:} THE BURDEN OF INFLUENZA DISEASE IN HIV

HIV infection is associated with deficiencies in both humoral and cell-mediated immunity, which alter the course of common infections (8). The efficacy of influenza vaccines is compromised, in part, by reduced antibody responses observed in HIV-infected individuals (9). While highly active antiretroviral therapy (HAART) partially restores these deficiencies, $\mathrm{HIV}$-infected persons may remain at increased risk for morbidity from viral illness, especially if the ability to generate antigen-specific responses remains impaired. Additional factors such as high prevalence of smoking, inhaled narcotic use and chronic lung diseases in some HIV-infected populations may further predispose these individuals to respiratory tract infection (10).

Despite the widespread risk factors and common occurrence of influenza syndrome, there are limited published data related to the frequency and severity of influenza illness in HIVinfected individuals. The risk for influenza-related death is estimated to be 9.4 to 14.6 per 10,000 in persons with AIDS, compared with 0.09 to 0.10 per 10,000 among all persons 25 to 54 years of age, and 6.4 to seven per 10,000 among persons 65 years of age and older (11). In another study (12), the risk for cardiopulmonary hospitalizations among women with HIV infection was higher during influenza seasons than during the peri-influenza periods. In this report, the risk for hospitalization was higher for HIV-infected women than for women with other well-recognized high-risk conditions, including chronic heart and lung diseases.

Other reports $(2,3,13)$ indicate that influenza symptoms may be prolonged, and the risk for complications from influenza may be increased. HIV infection may predispose individuals to increased susceptibility to influenza infection, prolonged viral replication and shedding, longer duration of influenza symptomatology and higher influenza-related mortality (4). Klein et al (14) noted that influenza was responsible for at least $40 \%$ of all febrile respiratory illnesses among an influenza-vaccinated outpatient population of HIVinfected patients over two consecutive influenza seasons. Ninety per cent of these patients were on HAART, with a median CD4 count of 325 cells/ $\mathrm{LL}$ and an HIV RNA level below 50 copies $/ \mathrm{mL}$.

\section{CURRENT STATE OF CLINICAL KNOWLEDGE}

\section{Randomized and nonrandomized evidence}

Several groups have attempted to evaluate the efficacy of influenza vaccine in those living with HIV (Table 1). Controlled trials of single-dose inactivated influenza vaccine in HIV-infected adults demonstrated safety, but suboptimal antibody responses (15). It is key to note that the study did not evaluate patients on HAART and, thus, the results are not fully applicable to current HIV populations followed in the developed world.

Immunogenicity studies $(4,9)$ in post-HAART era patients have confirmed the production of protective antibodies in
HIV-infected persons, but the titres appear to be lower than in those persons without HIV. Influenza vaccination has been demonstrated to produce substantial antibody levels in HIVseropositive persons with minimal or no AIDS-related symptoms and high CD4 counts (16-19). A randomized, placebo-controlled trial (20) determined that inactivated influenza vaccine was highly effective in preventing symptomatic, laboratory-confirmed influenza virus infection among HIV-infected persons with a mean CD4+ T lymphocyte count of 400 cells $/ \mathrm{mm}^{3}$. Not all studies have demonstrated such good influenza vaccination efficacy in HAART-treated populations with high CD4 counts (14). In the Klein et al (14) study, the vaccination rate was $76 \%$ among those subsequently developing respiratory illness, suggesting poor clinical efficacy.

A limited number of persons with CD4+ T lymphocyte cell counts of lower than 200 cells $/ \mathrm{mm}^{3}$ were included in the Tasker et al (20) study, which precludes conclusions related to clinical outcomes in the profoundly immunocompromised HIV population. Clearly, the likelihood of achieving seroprotective antibodies is diminished with advanced HIV disease $(18,19)$. A nonrandomized study (13) among HIV-infected persons determined that influenza vaccination was less effective in preventing disease among persons with CD4 counts lower than 100 cells/ $\mu \mathrm{L}$ and among those with HIV viral loads above 30,000 copies/mL (13).

\section{FINDINGS FROM RECENT SYSTEMATIC REVIEW AND META-ANALYSIS}

As a consequence of conflicting data, reduced antibody response to influenza vaccine and uncertainty related to the efficacy in preventing influenza disease in HIV patients, our group conducted our own meta-analysis (7). Ten relevant electronic databases were searched using a systematic strategy developed in conjunction with both clinical experts and library technicians (from inception to June 2007), and a total of seven potentially relevant citations were identified that were subsequently reduced to four articles (13,20-22) (methodological details of these studies are summarized in our review article [7]). Data were extracted on study design, population characteristics and on outcomes related to influenza symptoms and hemagglutination inhibition (HI) titres. Data were pooled using a random effects model, and sensitivity analyses were conducted to evaluate potential sources of heterogeneity.

Three of the included studies were evaluable for metaanalysis and yielded a pooled RR reduction of $66 \%$ (95\% CI 36 to $82, I^{2}=73 \%$ ) for influenza in those vaccinated compared with controls (7). When the heterogeneity was assessed according to study design and study quality, only one randomized clinical trial (20) remained, which yielded the most conservative estimate (RR reduction of 41\% [95\% CI 2 to 64]). This analysis is relevant to the typical HIV populations followed in Canadian clinics because $56 \%$ to $96 \%$ of those evaluated were on HAART. The median CD4 count was greater than 400 cells $/ \mu \mathrm{L}$ in these selected evaluations. Unfortunately, this sample was too small to assess the influence of antiretroviral therapy, CD4 count or HIV viral load on vaccine effectiveness. Based on the findings, it was concluded that current evidence evaluating influenza vaccination within the HIV population is sparse, and is characterized by a variety of important methodological shortcomings. 
TABLE 1

Characteristics of key influenza vaccine studies in HIV-positive adults

\begin{tabular}{|c|c|c|c|c|c|c|c|}
\hline $\begin{array}{l}\text { Author, year, } \\
\text { reference }\end{array}$ & $\mathbf{n}$ & Study design & Active & Control & Vaccine strain & Baseline measurement & Outcome measurement \\
\hline $\begin{array}{l}\text { Miotti, } 1989 \\
\text { (24) }\end{array}$ & 109 & $\begin{array}{l}\text { Single-arm, } \\
\text { booster dose }\end{array}$ & $\begin{array}{l}\text { Booster dose } \\
\text { one month } \\
\text { postinitial dose }\end{array}$ & - & $\begin{array}{l}\text { A/Taiwan/1/86 (H1N1), } \\
\text { A/Leningrad/360/86 (H3/N2), } \\
\text { B/Ann Arbor/1/86 }\end{array}$ & $\begin{array}{l}\text { CD4 count }(n=67) \\
\text { Zidovudine use }(n=13) \\
\text { Influenza antibody titre }\end{array}$ & Influenza antibody titre \\
\hline $\begin{array}{l}\text { Iorio, } 1997 \\
\text { (25) }\end{array}$ & 126 & $\begin{array}{l}\text { Single-arm, } \\
\text { booster dose }\end{array}$ & $\begin{array}{l}\text { Booster dose } \\
\text { one month } \\
\text { postinitial dose }\end{array}$ & $\begin{array}{l}- \\
-\end{array}$ & $\begin{array}{l}\text { A/Beijing/32/92 (H3/N2), } \\
\text { A/Singapore/6/86 (H1N1), } \\
\text { B/Panama/45/90 }\end{array}$ & $\begin{array}{l}\text { CD4 count } \\
\text { Influenza antibody titre }\end{array}$ & $\begin{array}{l}\text { Influenza antibody titre } \\
\text { Influenza virus from } \\
\text { throat swabs }\end{array}$ \\
\hline $\begin{array}{l}\text { Tasker, } 1999 \\
\text { (20) }\end{array}$ & 102 & Randomized & $\begin{array}{l}\text { Vaccinated } \\
\qquad(n=47)\end{array}$ & $\begin{array}{l}\text { Placebo } \\
\qquad(n=55)\end{array}$ & $\begin{array}{l}\text { A/Johannesburg 33/94 } \\
\text { (H3N2), A/Texas 36/91 } \\
\text { (H1N1), B/Harbin 07/94 }\end{array}$ & $\begin{array}{l}\text { CD4 count } \\
\text { Plasma HIV-1 RNA } \\
\text { Influenza antibody titre } \\
\text { HAART use }\end{array}$ & $\begin{array}{l}\text { Influenza antibody titre } \\
\text { Change in HAART } \\
\text { regimen } \\
\text { Viral culture } \\
\text { Flu symptoms: rhinitis, } \\
\text { pharyngitis, cough }\end{array}$ \\
\hline $\begin{array}{l}\text { Kroon, } 2000 \\
\text { (19) }\end{array}$ & 155 & $\begin{array}{l}\text { Single-arm, } \\
\text { double-dose } \\
\text { vaccine }\end{array}$ & $\begin{array}{l}\text { Double-dose } \\
\text { vaccination } \\
(30 \mu \mathrm{g} \mathrm{HI} \text { antigen })\end{array}$ & - & $\begin{array}{l}\text { Differed by year of } \\
\text { enrolment (1991-92, } \\
\text { 1992-93, 1993-94) }\end{array}$ & $\begin{array}{l}\text { CD4 count } \\
\text { Influenza antibody titre } \\
\text { Antiretroviral use }\end{array}$ & $\begin{array}{l}\text { Influenza antibody titre } \\
\text { CD4 count }\end{array}$ \\
\hline $\begin{array}{l}\text { Fine, } 2001 \\
\text { (13) }\end{array}$ & 71 & Case-control & Vaccinated & Unvaccinated & $\begin{array}{l}\text { A/Nanchang 933/95 (H3N2), } \\
\text { A/Texas 36/91 (HINI), } \\
\text { B/Harbin 07/94, } \\
\text { York 83/97 (H3N2) }\end{array}$ & $\begin{array}{l}\text { CD4 count } \\
\text { Plasma HIV-1 RNA } \\
\text { Influenza antibody titre } \\
\text { HAART use }\end{array}$ & $\begin{array}{l}\text { Flu symptoms: } \\
\geq 37.8^{\circ} \mathrm{C} \text { and presence } \\
\text { of cough/sore throat, } \\
\text { and fourfold increase in } \\
\text { antibody titre or } \\
\text { laboratory isolation of } \\
\text { influenza illness }\end{array}$ \\
\hline $\begin{array}{l}\text { Yamanaka, } \\
2005 \text { (21) }\end{array}$ & 328 & Cohort & $\begin{array}{l}\text { Vaccinated } \\
\qquad(n=262)\end{array}$ & $\begin{array}{l}\text { Unvaccinated } \\
\qquad(\mathrm{n}=66)\end{array}$ & $\begin{array}{l}\text { A/New Caledonia 20/99 } \\
\text { (H1N1), A/Panama 2007/99, } \\
\text { (H3N2), B/Shanton } 7 / 87\end{array}$ & $\begin{array}{l}\text { CD4+ cell counts } \\
\text { Plasma HIV-1 RNA } \\
\text { Influenza antibody titre } \\
\text { HAART use }\end{array}$ & $\begin{array}{l}\text { Flu symptoms: } \geq 38^{\circ} \mathrm{C}, \\
\text { and two of the five } \\
\text { following clinical } \\
\text { symptoms: cough, } \\
\text { rhinitis, myalgia, sore } \\
\text { throat and headache; } \\
\text { and fourfold increase in } \\
\text { antibody titre }\end{array}$ \\
\hline $\begin{array}{l}\text { Ranieri, } 2005 \\
\text { (22) }\end{array}$ & 145 & Cohort & $\begin{array}{l}\text { Covaccine - } \\
\text { pneumococcal } \\
\text { and influenza } \\
(n=90)\end{array}$ & $\begin{array}{l}\text { Pneumococcal } \\
\text { vaccine } \\
(n=55)\end{array}$ & INFLEXAL V, Berna & $\begin{array}{l}\text { CD4+ cell counts } \\
\text { Plasma HIV-1 RNA } \\
\text { HAART use }\end{array}$ & Influenza illness \\
\hline
\end{tabular}

HAART Highly active antiretroviral therapy; HI Hemagglutination inhibition

\section{EFFICACY OF BOOSTER INFLUENZA VACCINATION IN HIV}

One potential means of achieving higher seroprotection rates with vaccination in HIV patients may be to administer a booster dose of influenza vaccine (23). The efficacy of a booster-dose strategy administered over a one-month period was evaluated in a small pre-HAART era population (24). A total of 109 patients were enrolled - HIV-seronegative heterosexual men $(n=11)$, HIV-seronegative homosexual men ( $n=20)$, asymptomatic HIVseropositive men $(n=32)$, HIV-seropositive men with AIDSrelated complex (ARC) $(n=9)$ and HIV-seropositive men with AIDS $(n=37)$. CD4 T lymphocyte counts were available in 67 HIV patients (asymptomatic $527 \pm 252$ cells $/ \mu \mathrm{L}$, ARC $295 \pm 172$ cells $/ \mu \mathrm{L}$ and AIDS $128 \pm 116$ cells $/ \mu L)$. Baseline HIV RNA levels were not available. Thirteen AIDS patients were on zidovudine monotherapy at the time of vaccination. The median age in the groups ranged from 33 to 41 years. Recipients received $15 \mu \mathrm{g}$ of trivalent influenza virus subvirion vaccine from the same lot (A/Taiwan/1/86[H1N1], A/Leningrad/360/86[H3/N2] and B/Ann Arbor/1/86). The frequency of seroconversion for each influenza $A$ vaccine antigen ranged from $55 \%$ to $75 \%$ after the first dose in HIV-infected patients, and this increased marginally following the second dose $(73 \%$ to $80 \%)$. The ability of HIV-infected patients to respond serologically to one or both antigens was inversely related to the severity of their HIV disease. After a single dose of vaccine, asymptomatic HIV patients with prevaccination antibody titres of 1:16 or less achieved seroconversion as frequently as non-HIV infected participants (ie, HIV-seronegative heterosexuals and HIV-seronegative homosexuals, respectively) (A/Taiwan $80 \%$ versus 71\%, 93\%; $\mathrm{A} /$ Leningrad $84 \%$ versus 92\%, 100\%; and B/Ann Arbor 37\% versus 65\%, 70\%). Patients with more advanced HIV disease had low seroconversion rates (A/Taiwan 38\% to 67\%, A/Leningrad $0 \%$ to $67 \%$ and B/Ann Arbor $12 \%$ to $22 \%)$. The booster had little or no effect in increasing the proportion with protective antibody levels in asymptomatic HIV patients or those with ARC/AIDS. The two-dose schedule produced a minimum fourfold increase in $\mathrm{HI}$ antibodies to each of the vaccine antigens, more often in HIV-seronegative participants than those with AIDS/ARC 
(A/Taiwan 90\% versus 55\%, $\mathrm{P}=0.07$; $\mathrm{A} /$ Leningrad $84 \%$ versus $30 \%, \mathrm{P}<0.01$ and $\mathrm{B} / \mathrm{Ann}$ Arbor $56 \%$ versus $20 \%, \mathrm{P}=0.03)$. In conclusion, there was a significantly lower antibody response to all antigens in AIDS/ARC patients compared with HIVseronegative controls. Postbooster antibody titre was found to be correlated with CD4 $\mathrm{T}$ cell count $(\mathrm{P}<0.03)$. Of note, there was a trend that AIDS patients on zidovudine may have benefited from the booster. This final observation raises the issue of if, and to what degree, HAART affects the effect of booster influenza vaccination.

Iorio et al (25) also concluded that booster dosing of influenza vaccine was ineffective at achieving higher antibody titres in a group of former injection drug user HIV-seropositive individuals. This work was again limited by small sample size, lack of description of clinical status and the fact that it was conducted on a pre-HAART population.

Although the Centers for Disease Control and Prevention references the above data in support of the statement that administration of a booster dose is not beneficial in achieving greater seroprotective titres in HIV-infected patients (6), there are multiple concerns, which call into question whether this conclusion is justified. These studies were conducted in a preHAART era. The influence of current HIV treatment on influenza vaccine response is not well described. There is no literature available on the efficacy of a booster strategy in the post-HAART era. The sample sizes were small and the studies were not randomized. Furthermore, clinical outcomes were not assessed. As a consequence of these multiple shortcomings, the value of an influenza booster-dose strategy in HIV patients in the post-HAART era remains unsettled.

\section{PAUCITY OF PUBLISHED EVIDENCE FOR INCREASED ANTIGENIC CONTENT OF INFLUENZA VACCINE ANTIGENS}

There is next to no literature evaluating the efficacy of increased influenza vaccine antigen dose in HIV-infected patients. Kroon et al (19) evaluated the effect of doubling the hemagglutinin antigenic content to $30 \mu \mathrm{g}$ in a cohort of HIVinfected patients and concluded that this strategy was ineffective in augmenting antibody response. However, there was no randomized comparison arm, the sample size was small and the study was conducted in the pre-HAART period. The majority of participants were profoundly immunocompromised. No correlation between antibody production and clinical illness was reported.

Use of an increased antigen dose to produce higher neutralizing antibody titres has been effective in other populations. A study (26) of escalating doses of hemagglutinin antigen $(4 \mu \mathrm{g}$ to $61 \mu \mathrm{g})$ in immunocompetent recipients demonstrated a correlation between antigen dose and higher HI antibody titre. This strategy may benefit immunocompromised populations. A randomized, controlled study (27) of double-dose vaccination was conducted in a population of frail elderly patients (27). The first vaccine dose $(15 \mu \mathrm{g}$ versus $30 \mu \mathrm{g})$ was followed 84 days later by a second injection (placebo versus $15 \mu \mathrm{g}$ ). Twenty-five days after the initial injection, the geometric mean titre in the double-dose recipients was $15 \%$ greater (95\% CI 6 to 24; $\mathrm{P}=0.001$ ), supporting the strategy of higher antigen dosing. The geometric mean titre in booster recipients was $14 \%$ higher (95\% CI 9 to 19; $\mathrm{P}=0.001$ ) compared with placebo, which supports the strategy of booster dosing. A shortcoming of this work was that clinical outcomes were not described.
High antigen dose was evaluated in a group of healthy volunteers vaccinated with an experimental $\mathrm{H} 5 \mathrm{~N} 1$ strain influenza vaccine (28). Although the overall results were disappointing, there was a clear dose-response relationship between hemagglutinin antigen dosing and antibody titres (defined as a minimum of 1:40), when assessed by HI assay and microneutralization testing $(\mathrm{P}<0.001)$. The use of $90 \mu \mathrm{g}$ of $\mathrm{H} 5 \mathrm{~N} 1$ influenza virus strain hemagglutinin antigen followed by a booster dose 28 days later produced higher titres in a greater proportion of randomly assigned study participants after both the first and booster dose of the vaccine. Twenty-eight per cent, $23 \%, 10 \%, 5 \%$ and $0 \%$ of patients developed HI titres of a minimum of 1:40, 28 days after the first antigen dose $(90 \mu \mathrm{g}, 45 \mu \mathrm{g}$, $15 \mu \mathrm{g}, 7.5 \mu \mathrm{g}$ and $0 \mu \mathrm{g}$ ). Similar results were observed for microneutralization titres. After injection of a booster dose of vaccine, desired $\mathrm{HI}$ titres were achieved in 57\%, 41\%, 24\%, $13 \%$ and $0 \%$ of recipients of $90 \mu \mathrm{g}, 45 \mu \mathrm{g}, 15 \mu \mathrm{g}, 7.5 \mu \mathrm{g}$ and $0 \mu \mathrm{g}$ antigen doses $(\mathrm{P}<0.001)$. The study further demonstrated the principal that higher antibody titres can be produced by use of higher antigen dosing and by booster dosing of vaccine.

\section{IMPLICATIONS AND FURTHER RESEARCH}

There exists an important burden of influenza infection in HIV patients that should be addressed by identifying effective preventive strategies. The current standard approach to prophylaxis with influenza vaccine is less effective in immunocompromised individuals, such as those living with HIV. Our review of past trials evaluating influenza vaccination in HIV patients demonstrates the limited comparability of these study populations to present day HIV-seropositive individuals. Although there is some efficacy, it is suboptimal. To address this, alternative vaccination approaches need to be assessed in current patient populations. The efficacy of booster doses of influenza vaccine in HIV patients remains uncertain because of the methodological shortcomings in study design and outcome measurement of published past research. Furthermore, there is currently a paucity of published evidence assessing the efficacy of an increased, double-dose of influenza vaccine in this patient population. Immunogenicity studies with adjuvants do exist, but the utility of this approach is limited by minimal adjuvant availability and increased expense. Another option for improving vaccine efficacy in immunocompetent populations is the use of live attenuated influenza vaccine. However, live vaccine use is not recommended in the HIVinfected population.

To address this issue, a randomized, multicentred Canadian study of HIV-seropositive adults will be conducted in the fall of 2008, evaluating seroprotective HI titre production, protection from flu-like illness and laboratory-documented influenza infection. Three influenza vaccine strategies will be evaluated in 285 participants - current standard of care, single-dose influenza injection; the same followed by a booster dose injection 28 days after the first; and double-dose influenza vaccine injection followed by the same, 28 days later. Fluviral (GlaxoSmithKline Biologicals North America, Canada) will be used. The study is supported by the Public Health Agency of Canada, The Ontario HIV Treatment Network and the Canadian HIV Trials Network.

No one trial can definitely resolve all questions related to the effectiveness of a common therapeutic intervention. However, we hope that this work will produce new knowledge that will strengthen evidence-based influenza vaccination guidelines and protect those living with HIV from the serious consequences of influenza disease. 


\section{REFERENCES}

1. Boulos D, Yan P, Schanzer D, Remis RS, Archibald CP.

Estimates of HIV prevalence and incidence in Canada, 2005.

Can Commun Dis Rep 2006;32:165-74.

2. Safrin S, Rush JD, Mills J. Influenza in patients with human immunodeficiency virus infection. Chest 1990;98:33-7.

3. Radwan HM, Cheeseman SH, Lai KK, Ellison IR. Influenza in human immunodeficiency virus-infected patients during the 1997-1998 influenza season. Clin Infect Dis 2000;31:604-6.

4. Zanetti AR, Amendola A, Besana S, Boschini A, Tanzi E. Safety and immunogenicity of influenza vaccination in individuals infected with HIV. Vaccine 2002;20(Suppl 5):B29-32.

5. Health Canada. Progress towards Canadian target coverage rates in influenza and pneumococcal immunications. $<$ http://www.phac-aspc.gc.ca/publicat/ccdr-rmtc/01vol27/ dr2710eb.html> (Version current at December 8, 2006).

6. Advisory Committee on Immunization Practices; Smith NM, Bresee JS, Shay DK, Uyeki TM, Cox NJ, Strikas RA. Prevention and control of influenza: Recommendations of the Advisory Committee on Immunization Practices (ACIP). MMWR Recomm Rep 2006;55:1-42. (Erratum in 2006;55:800).

7. Anema A, Mills E, Montaner J, Brownstein JS, Cooper C. Efficacy of influenza vaccination in HIV-positive patients: A systematic review and meta-analysis. HIV Med 2008;9:57-61.

8. Beck JM, Rosen MJ, Peavy HH. Pulmonary complications of HIV infection. Report of the Fourth NHLBI Workshop. Am J Respir Crit Care Med 2001;164:2120-6.

9. Malaspina A, Moir S, Orsega SM, et al. Compromised B cell responses to influenza vaccination in HIV-infected individuals. J Infect Dis 2005;191:1442-50.

10. Conley LJ, Bush TJ, Buchbinder SP, Penley KA, Judson FN, Holmberg SD. The association between cigarette smoking and selected HIV-related medical conditions. AIDS 1996;10:1121-6.

11. Lin JC, Nichol KL. Excess mortality due to pneumonia or influenza during influenza seasons among persons with acquired immunodeficiency syndrome. Arch Intern Med 2001;161:441-6.

12. Neuzil KM, Reed GW, Mitchel E Jr, Griffin MR. Influenzaassociated morbidity and mortality in young and middle-aged women. JAMA 1999;281:901-7.

13. Fine AD, Bridges CB, De Guzman AM, et al. Influenza A among patients with human immunodeficiency virus: an outbreak of infection at a residential facility in New York City. Clin Infect Dis 2001;32:1784-91.

14. Klein MB, Lu Y, DelBalso L, Cote S, Boivin G. Influenza virus infection is a primary cause of febrile respiratory illness in HIV-infected adults, despite vaccination. Clin Infect Dis 2007;45:234-40.
15. Ragni MV, Ruben FL, Winkelstein A, Spero JA, Bontempo FA, Lewis JH. Antibody responses to immunization of patients with hemophilia with and without evidence of human immunodeficiency virus (human T-lymphotropic virus type III) infection. J Lab Clin Med 1987;109:545-9.

16. Chadwick EG, Chang G, Decker MD, Yogev R, Dimichele D, Edwards KM. Serologic response to standard inactivated influenza vaccine in human immunodeficiency virus-infected children. Pediatr Infect Dis J 1994;13:206-11.

17. Huang KL, Ruben FL, Rinaldo CR Jr, Kingsley L, Lyter DW, Ho M. Antibody responses after influenza and pneumococcal immunization in HIV-infected homosexual men. JAMA 1987;257:2047-50.

18. Staprans SI, Hamilton BL, Follansbee SE, et al. Activation of virus replication after vaccination of HIV-1-infected individuals. J Exp Med 1995;182:1727-37.

19. Kroon FP, van Dissel JT, de Jong JC, Zwinderman K, van Furth R. Antibody response after influenza vaccination in HIV-infected individuals: A consecutive 3-year study. Vaccine 2000;18:3040-9.

20. Tasker SA, Treanor JJ, Paxton WB, Wallace MR. Efficacy of influenza vaccination in HIV-infected persons. A randomized, double-blind, placebo-controlled trial. Ann Intern Med 1999;131:430-3.

21. Yamanaka H, Teruya K, Tanaka M, et al. Efficacy and immunologic responses to influenza vaccine in HIV-1-infected patients. J Acquir Immune Defic Syndr 2005;39:167-73.

22. Ranieri R, Veronelli A, Santambrogio C, Pontiroli AE. Impact of influenza vaccine on response to vaccination with pneumococcal vaccine in HIV patients. AIDS Res Hum Retroviruses 2005;21:407-9.

23. Nichol KL. Booster doses of influenza vaccine. JAMA 1996;276:1857.

24. Miotti PG, Nelson KE, Dallabetta GA, Farzadegan H, Margolick J, Clements ML. The influence of HIV infection on antibody responses to a two-dose regimen of influenza vaccine. JAMA 1989;262:779-83.

25. Iorio AM, Alatri A, Francisci D, et al. Immunogenicity of influenza vaccine (1993-94 winter season) in HIV-seropositive and seronegative ex-intravenous drug users. Vaccine 1997;15:97-102.

26. Antibody responses and reactogenicity of graded doses of inactivated influenza A/New Jersey/76 whole-virus vaccine in humans. J Infect Dis 1977;136(Suppl):S475-83.

27. Roos-Van Eijndhoven DG, Cools HJ, Westendorp RG, Ten Cate-Hoek AJ, Knook DL, Remarque EJ. Randomized controlled trial of seroresponses to double dose and booster influenza vaccination in frail elderly subjects. J Med Virol 2001;63:293-8

28. Treanor JJ, Campbell JD, Zangwill KM, Rowe T, Wolff M. Safety and immunogenicity of an inactivated subvirion influenza A (H5N1) vaccine. N Engl J Med 2006;354:1343-51. 


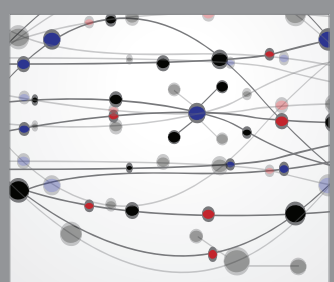

The Scientific World Journal
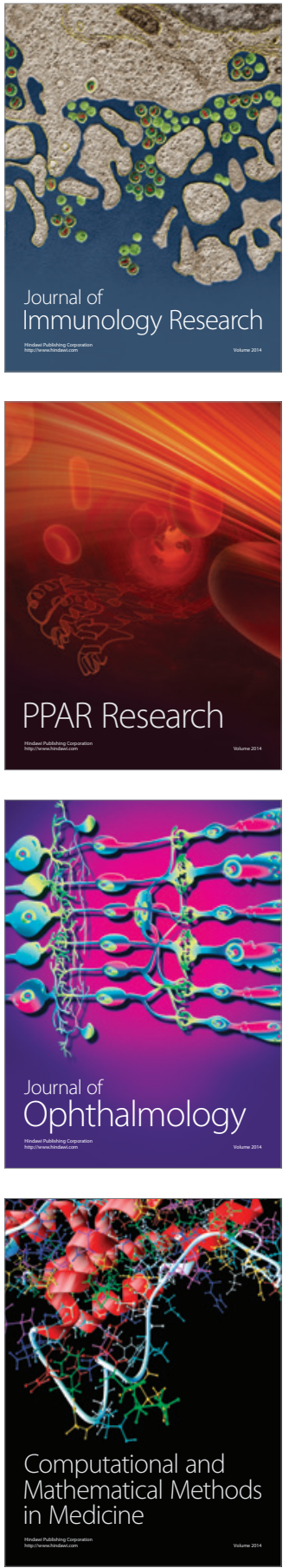

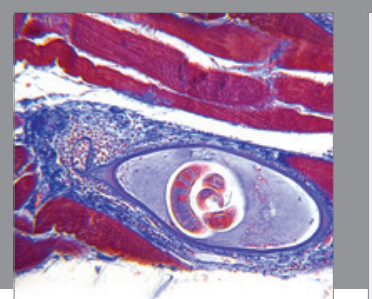

Gastroenterology Research and Practice

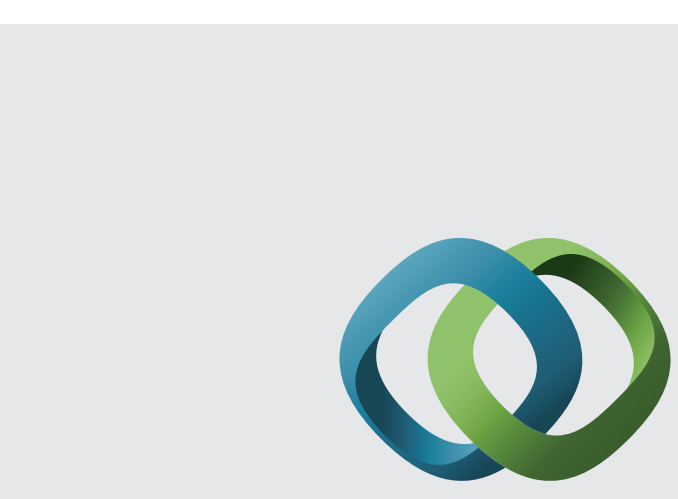

\section{Hindawi}

Submit your manuscripts at

http://www.hindawi.com
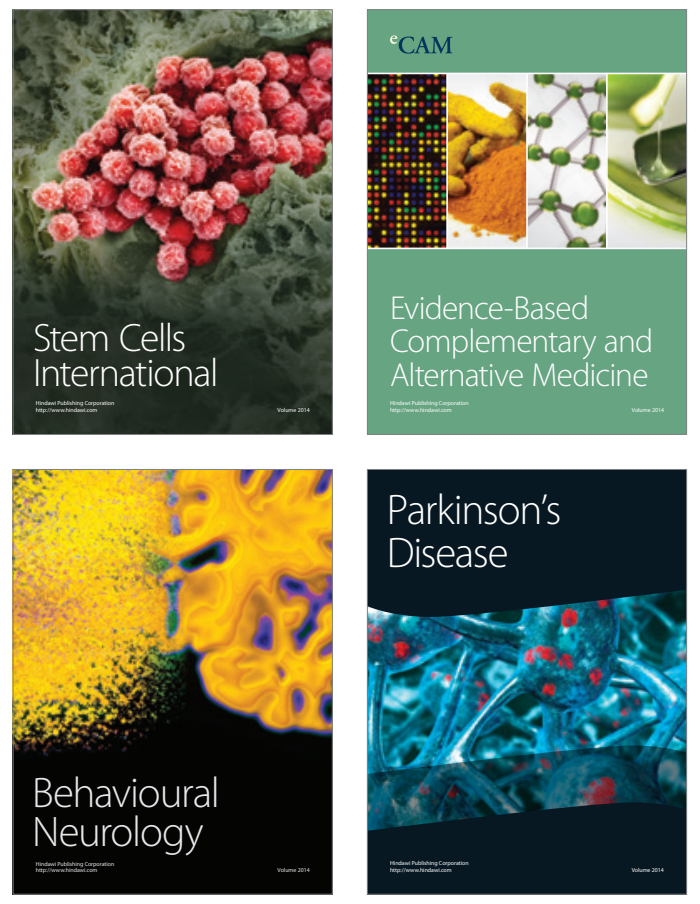
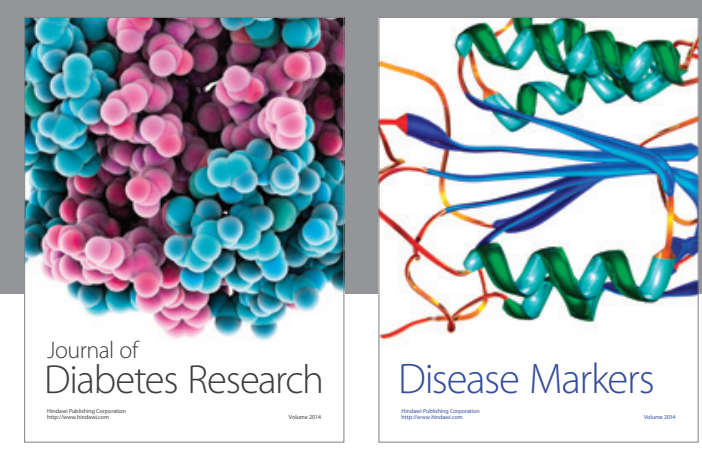

Disease Markers
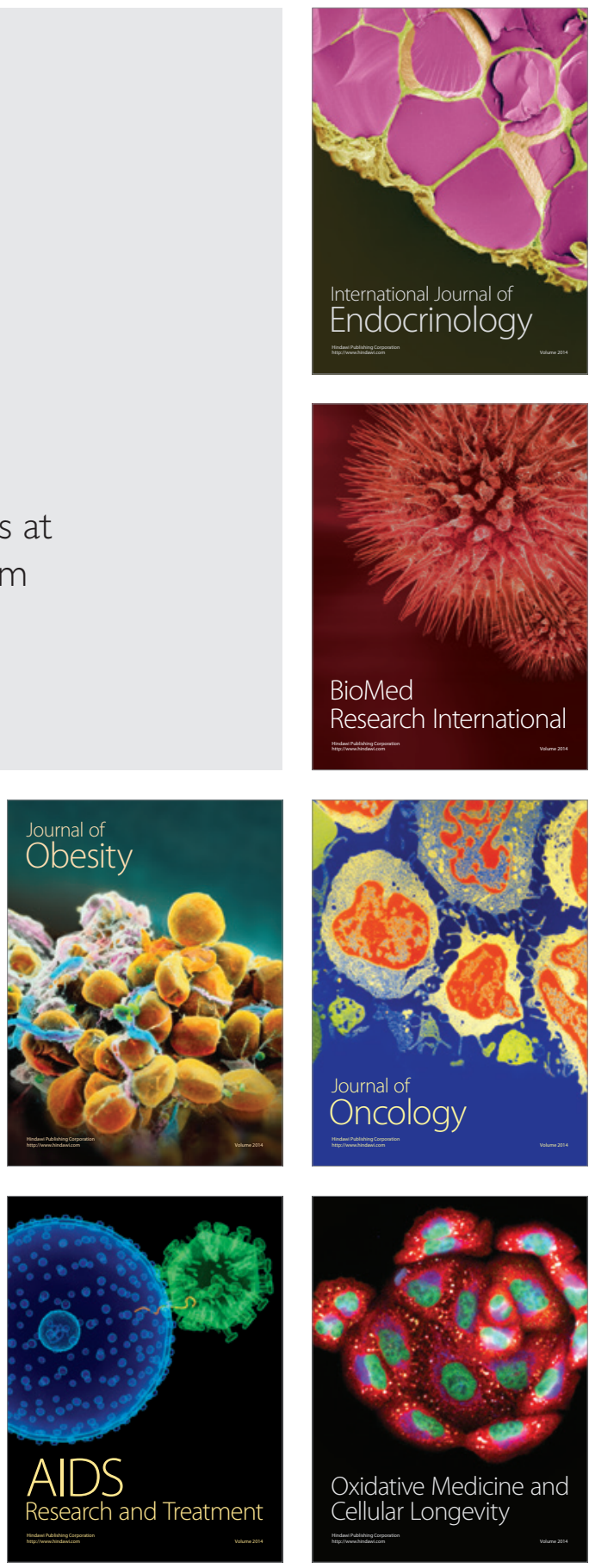